\title{
Studi Tentang Perubahan Adaptasi dan Interaksi Sosial Mahasiswa (Studi pada Mahasiswa Perantau di Jakarta yang Terdampak Pandemi Covid-19)
}

\author{
Karn Bell ${ }^{1}$, Suzy S. Azeharie ${ }^{2 *}$ \\ ${ }^{1}$ Fakultas Ilmu Komunikasi, Universitas Tarumanagara, Jakarta \\ Email: karnbell48@gmail.com \\ ${ }^{2}$ Fakultas Ilmu Komunikasi, Universitas Tarumanagara,, Jakarta* \\ Email: suzya@fikom.untar.ac.id
}

Masuk tanggal :15-12-2021, revisi tanggal :06-01-2022, diterima untuk diterbitkan tanggal : 16-01-2022

\begin{abstract}
The Covid-19 virus is a new type of coronavirus that can be transmitted to humans. This virus may spread everyone including infants, children, adults, the elderly, pregnant women, and nursing mom. The spread of this virus can occur through physical contact or indirectly if you pass or come into contact with people who have been infected. The pandemic due to this virus affects various aspects of human activities, especially in the aspect of social interaction. Changes that occur in the social environment make people try to make social adaptations directly or indirectly affects the lifestyle of the community, including overseas students. This study aims to determine the changes in social interactions that occur in the lives of overseas students in the midst of the pandemic. This research uses Social Interaction theory and Social Adaptation theory. This research uses descriptive qualitative research with phenomenological research methods. The results of the study were obtained through observation data, interviews, and documentation of three interviewee. This study concludes that there are social changes, making the lifestyle of overseas students in Jakarta also change according to the rules during the pandemic in terms of finance, health, and communication. The social changes felt by overseas students foster a sense of sympathy and concern for the condition of others. It can be seen from the experience of the students who help others for sharing some foods and the emotional level of an incident of other individuals.
\end{abstract}

Keywords: adaptation, changes, interaction, lifestyle

\begin{abstract}
Abstrak
Virus Covid-19 adalah virus baru dari Corona Virus dan dapat menular ke manusia. Virus ini menyerang semua orang mulai dari bayi hingga lansia, bahkan ibu hamil dan ibu menyusui. Penyebaran virus ini dapat terjadi melalui kontak fisik seperti berpapasan atau bersentuhan langsung dengan orang yang sudah terpapar. Pandemi akibat virus ini mempengaruhi berbagai aspek kehidupan manusia terutama dalam aspek berinteraksi sosial. Perubahan yang terjadi di lingkungan sosial membuat orang mencoba melakukan adaptasi sosial dan hal tersebut langsung maupun tidak langsung berpengaruh terhadap gaya hidup masyarakat terutama mahasiswa perantau. Penelitian ini bertujuan untuk mengetahui perubahan interaksi sosial yang terjadi di kehidupan mahasiswa perantau di tengah pandemi. Penelitian ini menggunakan teori Interaksi Sosial dan teori Adaptasi Sosial. Pada penelitian menggunakan jenis penelitian kualitatif deskriptif dengan metode penelitian fenomenologi. Hasil penelitian diperoleh melalui data observasi, wawancara, dan dokumentasi terhadap tiga narasumber. Penelitian ini menyimpulkan bahwa adanya perubahan sosial, membuat gaya hidup mahasiswa perantau di Jakarta turut berubah menyesuaikan aturan selama pandemi berlangsung darisegi finansial, kesehatan, dan komunikasi. Perubahan sosial yang dirasakan mahasiswa perantau menumbuhkan rasa simpati dan peduli terhadap kondisi sesama. Hal ini dilihat berdasarkan
\end{abstract}


pengalaman narasumber yang membantu sesama dalam berbagi makanan serta tingkat emosional akan suatu kejadian yang menimpa individu lain.

Kata Kunci: adaptasi, gaya hidup, interaksi, perubahan

\section{Pendahuluan}

Virus Covid-19 adalah virus baru dari Corona Virus yang dapat menular ke manusia. Virus ini dapat menyerang semua orang mulai dari bayi hingga lansia, bahkan ibu hamil dan ibu menyusui. Infeksi pertama kali ditemukan di kota Wuhan, Cina, Desember 2019. Penyebaran virus ini dapat terjadi melalui kontak fisik langsung jika berpapasan atau bersentuhan dengan individu yang sudah terpapar. Virus Covid-19 dapat menyebar dari satu individu ke individu lain melalui partikel cairan atau percikan yang dihasilkan orang-orang yang sudah terinfeksi melalui hidung dan mulut saat bersin, batuk atau ketika sedang berbicara (World Health Organization, 2021).

Pandemi akibat virus ini mempengaruhi berbagai aspek kehidupan manusia terutama dalam aspek berinteraksi sosial. Interaksi sosial menurut Gillin dan Gillin dalam Soekanto merupakan hubungan-hubungan sosial yang dinamis antara individu, antara kelompokdengan kelompok manusia, maupun antara individu dengan kelompok yang lain (Soekanto, 2015). Akibat kebijakan pembatasan sosial terhadap masyarakat yang dilakukan oleh pemerintah selama pandemi berlangsung, maka terjadi perubahan cara hidup masyarakat dalam melakukan interaksi di lingkungan sosial mereka. Lingkungan sosial merupakan situasi terjadinya komunikasi. Lingkungan sosial terdiri dari beberapa elemen, seperti waktu, tempat, periode, relasi, dan latar belakang budaya antara pembicara dan pendengar (West \& Turner, 2012). Sementara menurut Peter dan Olson, yang termasuk dalam lingkungan sosial adalah semua interaksi sosial yang terjadi di antara masyarakat (Peter \& Olson, 2014).

Perubahan yang terjadi di lingkungan sosial membuat orang mencoba melakukan adaptasi sosial dan hal tersebut langsung maupun tidak langsung berpengaruh terhadap gaya hidup masyarakat termasuk mahasiswa perantau. Gaya hidup menurut Philip Kotler dan Gary Armstrong, adalah pola hidup individu dalam kehidupan sehari-hari meliputi kegiatan, minat, dan pendapat individu tersebut. Hal ini menunjukkan pola perilaku seseorang dalam kehidupan sehari-hari secara menyeluruh (Kotler \& Armstrong, 2012).

Adaptasi sosial merupakan suatu proses penyesuaian individu, kelompok maupun unit sosial terhadap peraturan, proses perubahan atau suatu kondisi yang dibuat. Adaptasi merupakan proses perubahan individu dalam memberikan timbal balik terhadap perubahan di lingkungan dan dapat mempengaruhi keutuhan tubuh secara fisiologis maupun psikologis dan dapat menghasilkan perilaku yang berbeda (Hasanah, 2018).

Tujuan dari penelitian ini adalah untuk mengetahui perubahan adaptasi dan interaksi sosial mahasiswa perantau di Jakarta yang terdampak Covid-19. Penulis tertarik untuk meneliti perubahan yang terjadi pada kehidupan mahasiswa perantau terutama mengenai perubahan mereka dalam melakukan interaksi dengan lingkungan sosial disekitar. Penelitian ini dilakukan karena belum pernah ada yang meneliti tentang topik seperti yang penulis lakukan. 
Karn Bell, Suzy S. Azeharie: Studi Tentang Perubahan Adaptasi dan Interaksi Sosial Mahasiswa (Studi pada Mahasiswa Perantau di Jakarta yang Terdampak Pandemi Covid-19)

\section{Metode Penelitian}

Pada penelitian ini, penulis menggunakan metode penelitian kualitatif. Menurut Sugiyono, penelitian kualitatif merupakan metode yang didasarkan pada filsafat untuk meneliti pada kondisi obyek yang alamiah, dan memposisikan peneliti sebagai instrumen kunci serta pengumpulan data dilakukan secara triangulasi, kemudian analisis data bersifat induktif dan hasil lebih menekankan makna daripada generalisasi (Sugiyono, 2013). Penulis menggunakan pendekatan penelitian kualitatif deskriptif. Menurut Burhan Bungin dalam Widyawati, penelitian deskriptif adalah penelitian yang berusaha untuk menyelesaikan masalah menggunakan data dan hasil observasi sehingga harus melakukan penyajian data, menganalisis dan menginterpretasikan data tersebut (Widyawati, 2017). Menurut John Creswell dalam Haris Herdiansyah, ada beberapa model penelitian kualitatif, seperti studi kasus, fenomenologi, biografi, grounded-theory, dan etnografi (Herdiansyah, 2010).

Dalam penelitian ini penulis menggunakan metode fenomenologi. Tujuan dari metode fenomenologi ini adalah untuk memperoleh makna dari pengalaman hidup individu mengenai suatu gejala untuk mengetahui lebih jauh struktur kesadaran dalam pengalaman individu tersebut (Raco, 2010). Penulis menggunakan metode penelitian fenomenologi karena dalam penelitian ini, penulis ingin mengetahui dan meneliti fenomena yang ada tentang pengalaman mahasiswa perantau di Jakarta yang terdampak wabah Covid-19.

Dalam penelitian ini penulis menggunakan menggunakan beberapa metode pengumpulan data dengan wawancara mendalam bersama tiga narasumber yang merupakan mahasiswa/i perantau yang menetap di Jakarta dan terdampak wabah Covid-19. Obyek penelitian menurut Sugiyono adalah sebuah atribut atau bagian dari keadaan sosial tertentu yang dapat dipelajari dan ditarik kesimpulannya (Sugiyono, 2013). Dalam penelitian ini yang menjadi obyek penelitian adalah perubahan adaptasi dan interaksi sosial mahasiswa terutama mahasiswa perantau.

\section{Hasil Temuan dan Diskusi}

\section{Aktivitas Sebelum dan Selama Pandemi}

Berdasarkan wawancara dengan Alvina, ia mengatakan bahwa ada perubahan yang relatif signifikan yang dilakukan selama hidup di tengah pandemi. Sebelum pandemi ia sering keluar rumah empat sampai lima kali dalam seminggu karena harus mengikuti kegiatan perkuliahan secara langsung dan menghabiskan waktu yang lama di lingkungan kampus mengisi aktivitasnya selama di organisasi yang ia ikuti. Selama pandemi melanda, aktivitas Alvina menjadi terhambat dan berkurang, berbeda dengan seperti sebelum pandemi. Meskipun ia sudah mengikuti program vaksinasi sebanyak dua kali menggunakan Pfizer dan tidak mengalami gejala atau efek samping apapun namun aktivitasnya di luar rumah banyak berkurang. Alvina bercerita bahwa selama pandemi, kegiatannya di luar ruangan menjadi terbatas. Bepergian hanya satu sampai dua kali dalam seminggu atau bahkan tidak sama sekali. Ia cenderung menghabiskan waktu dan menjalani aktivitas di tempat tidur dan tidak melakukan kegiatan yang berat. Dari perubahan aktivitas tersebut, ia merasa bahwa dirinya menjadi lebih sehat dan bugar selama hidup di tengah pandemi.

"Untuk gaya hidup mungkin tidak ada perubahan yang signifikan namun lebih ke kalau dulu sering pergi keluar mungkin seminggu bisa 4-5 kali. Tapi sejak 
Corona ini mungkin keluar seminggu hanya satu sampai dua kali atau bahkan tidak ada pergi sama sekali jadi tidak ada menggunakan transportasi dalam bentuk apapun. Kemudian untuk kegiatan yang berubah pastinya dari tatap muka menjadi daring. Semua kegiatan perkuliahan dan organisasi yang biasanya bisa saya habiskan berjam-jam di lingkungan kampus menjadi daring dan banyak berdiam di kamar sendiri. Kemudian untuk kegiatan lainnya mungkin sejak Corona, saya menyadari kalau jadi jarang sekali bergerak, saya jadi lebih banyak menghabiskan waktu di tempat tidur karena semua kegiatan bisa saya lakukan di tempat tidur. Saya mengerjakan tugas buka laptop di atas tempat tidur, jadi selama beberapa bulan pandemi saya itu hanya menghabiskan waktu di tempat tidur, di kamar tidur saya, tidak banyak melakukan aktivitas yang lebih berat gitu. Nah, akhirnya setelah beberapa bulan, saya akhirnya rajin berolahraga. Setiap sore saya itu olahraga 30 menit kurang lebih setiap ada waktu luang senggang saya akan olahraga, jadi yang berubah itu hidup saya mungkin bisa dibilang menjadi lebih sehat karena rajin olahraga, kalau dulu sebelum Corona saya hampir tidak pernah olahraga yang melibatkan fisik saya. Biasanya hanya dihabiskan dengan jalan-jalan dengan jalan kaki ke kampus" (Alvina Oeyta, 03 November 2021).

Narasumber Caren mengungkapkan bahwa ia tidak terlalu suka bepergian jika tidak ada ajakan dari teman. Sebelum pandemi selain kesibukannya berkuliah, 32 Caren juga menyempatkan diri untuk pergi ke gimnasium tidak jauh dari tempat tinggalnya. Ia lebih suka memesan makanan melalui aplikasi Grab-Food atau GoFood karena tidak ingin repot memasak. Sebelum pandemi Caren sering kali menggunakan aplikasi e-commerce seperti Shopee untuk membeli barang keperluan seperti bahan makanan dan barang keperluan sehari-hari selama merantau. Namun selama pandemi, Caren merubah gaya hidupnya, seperti memasak makanannya sendiri. Selama pandemi untuk memenuhi kebutuhan hariannya, biasanya ia membeli bahan makanan dengan berbelanja ke supermarket secara langsung atau menggunakan aplikasi seperti Segari yang menyediakan bahan makanan sayur-sayuran.

Sedangkan Farel mengatakan bahwa sebelum pandemi, ia selalu menghabiskan waktu untuk berkumpul bersama teman kuliahnya di sekretariat organisasi pecinta alam bernama Sonarapala Mahasiswa Bina Nusantara Pecinta Alam. Ia bisa menghabiskan waktu diluar tempat tinggalnya untuk mengobrol dan duduk bersama teman-temannya dari pagi sampai dengan malam hari. Farel mengaku bahwa ia termasuk orang yang boros finansial terutama dalam membeli peralatan outdoor atau bepergian bersama teman temannya ke gunung atau ke pantai. Sebelum pandemi, Farel tidak memiliki pekerjaan sampingan tapi selama ada pandemi ia mulai menekuni suatu pekerjaan sampingan namun memilih untuk tidak memberitahu pekerjaan yang sedang ia tekuni. Dari pekerjaan sampingan tersebut, ia menjelaskan bahwa uang simpanan seperti uang jajan harian semakin bertambah.

\section{Finansial Selama Merantau di Jakarta}

Narasumber Alvina menjelaskan bahwa hingga saat ini ia masih dibiayai oleh orang tuanya untuk pemenuhan kebutuhan harian seperti uang jajan, uang makan dan keperluan bulanan. Sementara itu untuk biaya pendidikan serta tempat tinggal di Jakarta dibiayai oleh kakak kandungnya yang sudah bekerja diluar kota. Ia berkata bahwa dengan adanya penghasilan dari magang yang ia ikuti ini, tidak ada pengurangan biaya bulanan dari orang tuanya. Biasanya Alvina menyesuaikan biaya 
Karn Bell, Suzy S. Azeharie: Studi Tentang Perubahan Adaptasi dan Interaksi Sosial Mahasiswa (Studi pada Mahasiswa Perantau di Jakarta yang Terdampak Pandemi Covid-19)

harian miliknya, apabila uang yang ada masih mencukupi, ia akan menggunakannya untuk membeli makanan ringan dan minuman. Namun, selama pandemi Alvina berkata bahwa ia menjadi lebih hemat karena lebih memperhatikan kondisi keuangannya. Hal ini membuat Alvina sadar untuk mengatur finansialnya dan tergerak dalam mencari pekerjaan sampingan.

Wawancara dengan Caren menjelaskan bahwa untuk uang kuliah masih dibiayai oleh orang tuanya, sedangkan untuk biaya tempat tinggal dan uang bulanan tidak dari orang tua melainkan dari pekerjaan yang dijalani Caren. Selain menjalani kuliah, ia juga bekerja paruh waktu di salah satu toko kopi berjarak satu kilometer dari tempat tinggalnya. Namun ketika pandemi datang, Caren memutuskan untuk berhenti dari toko kopi Untuk perubahan finansial yang dialami secara keseluruhan, ia tidak pernah meminta lagi pada orang tuanya biaya untuk pemenuhan kebutuhan sehari-hari karena ia merasa sudah cukup dengan penghasilan yang ia peroleh dari pekerjaannya. tempat ia bekerja dengan alasan gaji yang ia terima dikurangi sebagai dampak dari pandemi.

"Sebelum pandemi sejujurnya lebih boros sih karena kuliah offline jadi lebih sering makan diluar dan jalan bareng temen gitu dan kehitung transport juga ya kalau ditotal sebenarnya untuk keseharian doang ditambah uang kos bisa empat juta. Setelah pandemi engga tahu kenapa jadi lebih hemat sedikit sih karena meskipun jadi jarang keluar main jalan bareng temen jadinya di kost an aja gitu seharian, listriknya yang nambah biaya jadi bisa sekitar tiga juta gitu. Sejujurnya karena sekarang punya pekerjaan tetap jadi lebih tenang dan bersyukur sih. Kalo untuk masalah hidup keseharian biaya nggak pernah kesulitan, hanya emang lebih sulit dan sedikit stress karena tidak bisa pulang ke kota asal saja. Untuk perubahan finansial secara keseluruhan ya pastinya kasian orang tua karena terdampak jadinya tidak pernah minta ke orang tua, karena kan aku juga udah punya pekerjaan tetap dan bisa menutup biaya hidup keseharian itu udah cukup sih, ya tahu diri aja tidak boros belanja barang yang tidak perlu dan makan masakan sendiri karena pasti kebersihan dan kesehatannya lebih terjamin" (Caren Villa, 29 November 2021).

\section{Timbul Minat dan Ketertarikan akan Sesuatu}

Sebelum pandemi ia menghabiskan uang untuk membeli minuman dan jajan di area sekitar kampus. Namun ia merasakan perubahan sejak pandemi melanda terutama dalam hal finansial sehingga timbul kesadaran untuk lebih berhemat dalam memenuhi kebutuhan. Alvina menjelaskan bahwa uang jajan dari orang tuanya sempat dikurangi. Oleh karena itu sejak pandemi, timbul minat dan ketertarikan untuk merubah pola pikirnya terhadap kondisi finansialnya dengan berusaha berhemat dan mencoba melamar praktik kerja magang guna menambah penghasilan.

Sedangkan Farel mengatakan bahwa dirinya memiliki ketertarikan dan minat untuk memulai pekerjaan sampingan. Selama pandemi ia mencoba memulai pekerjaan sampingan karena lebih banyak menghabiskan waktu di tempat tinggalnya sebab melakukan segala sesuatu secara daring. Dengan adanya pandemi ini ia mencoba memulai usaha melalui perangkat laptop miliknya. 


\section{Pandangan Mereka terhadap Perubahan selama Hidup Merantau di Tengah Wabah}

Menurut Alvina, pandangan seseorang akan perubahan tergantung dari masingmasing individu. Ada sebagian orang melihat perubahan gaya hidupnya selama pandemi menjadi tidak baik misalnya lebih banyak diam daripada bergerak. Namun untuk dirinya perubahan ini memberikan dampak yang positif dan merubah pola pikir serta gaya hidupnya. Menurutnya, perubahan gaya hidup di tengah pandemi bukan hanya diperlukan melainkan sudah menjadi tuntutan untuk menyesuaikan dengan situasi terkini.

Caren melihat perubahan ini dari dua sisi berbeda. Ia melihat sisi baik perubahan selama pandemi seperti kehidupan masyarakat menjadi lebih teratur, karena tidak banyak orang di luar rumah serta kondisi alam yang semakin membaik karena diberlakukannya pembatasan sosial di masyarakat. Dari sisi lain, Caren mengatakan bahwa dengan adanya perubahan di tengah pandemi ini membuat masyarakat kesulitan untuk melakukan mobilisasi dan komunikasi.

Sementara menurut Farel diperlukan suatu perubahan dalam melakukan suatu adaptasi. Dengan melihat jumlah kasus paparan virus Covid-19 yang meningkat, maka harus dilakukan suatu perubahan dalam masyarakat. Dengan adanya perubahan dan adaptasi yang baik, maka kondisi akan kembali normal seperti dulu sebelum adanya pandemi Covid-19.

\section{Adanya Simpati berupa Gerakan Hati untuk Melakukan Perubahan}

Alvina melihat dampak dari wabah ini membuat masyarakat kecil mengalami kesusahan terutama dalam hal ekonomi serta finansial. Dari dalam diri Alvina muncul rasa simpati sehingga setiap ia memesan makanan menggunakan jasa ojek daring ia memesan juga makanan untuk pengemudi ojek daring, Alvina berinisiatif untuk memesan porsi lebih untuk pengemudi ojek tersebut. Selain itu melihat banyak teman temannya yang kehilangan keluarga akibat wabah maka hal tersebut menggerakan hati Alvina untuk menjadi pribadi yang lebih baik, sabar dan ramah kepada orang lain.

"Iya, selama di tengah wabah ini ada beberapa peristiwa yang menggerakkan hati saya dan membuat saya melakukan beberapa perubahan. Karena wabah ini, saya melihat banyak sekali masyarakat kecil yang terdampak ekonominya, dari mereka yang sudah susah menjadi semakin susah. Nah karena saya adalah seorang mahasiswi yang merantau dan saya tinggal di kos-kosan, sebagian besar makan siang saya itu saya pesan melalui ojek online. Saya inisiatif setiap saya memesan makanan melalui ojek online, saya memesan satu porsi lebihan untuk ojek tersebut, jadi saya membelikan dia makanan atau kadang saya akan memberikan tip, uang bonus untuk ojek tersebut, apalagi kalau ojek yang mengantarkan makanan saya itu bapak-bapak yang sudah tua, kadang saya jadi sangat tidak tega melihatnya. Kemudian untuk kejadian lainnya, sangat banyak teman-teman di media sosial itu kehilangan keluarganya akibat wabah ini, saya turut merasakan kesedihan itu juga dan berangkat dari hal itu saya akhirnya berpikir bahwa semua orang pada saat ini sedang tidak baik-baik saja dan alangkah baiknya saya bisa menjadi orang yang lebih baik, lebih sabar, dan lebih ramah terhadap orang lain karena kita tidak pernah tahu apa yang sedang orang itu hadapi” (Alvina Oeyta, 22 November 2021). 
Caren mengungkapkan bahwa berita yang tersebar di media sosial tentang kasus kematian akibat virus Covid-19 membuatnya menjadi lebih hati-hati dalam menjaga diri. Selain itu Caren mengaku menjadi lebih peduli terhadap orang-orang terdekatnya seperti keluarga untuk mengingatkan mereka agar menjaga kondisi kesehatan dan mengurangi bepergian guna menghindari terpapar virus. Sedangkan Farel mengatakan bahwa dengan adanya pandemi ini, ia tergerak melakukan perubahan seperti mengikuti peraturan protokol kesehatan agar kerabat dan anggota keluarga serta teman-teman yang berada di sekitarnya tidak terjangkit virus Covid-19.

\section{Cara Narasumber Melakukan Adaptasi dengan Keadaan Pandemi}

Adaptasi merupakan proses perubahan individu dalam memberikan respon terhadap perubahan di lingkungan serta dapat mempengaruhi keutuhan tubuh baik secara fisiologis dan psikologis yang menghasilkan perilaku berbeda (Hasanah, 2018). Narasumber Alvina mengatakan bahwa selama pandemi ini lebih banyak menghabiskan waktu di kamar tanpa banyak berinteraksi dengan orang lain sehingga ia tidak merasa adanya tekanan untuk bersosialisasi.

Caren mengungkapkan caranya beradaptasi terhadap perubahan ini yaitu dengan menjalaninya seperti biasa mengikuti aturan yang berlaku di lingkungan. Misalnya keluar rumah memakai masker ganda dll. Selain itu menurutnya cara beradaptasi yang baik seperti membuka pikiran lebih luas agar dapat melihat suatu perubahan dari sudut pandang yang berbeda.

Farel mengatakan bahwa dirinya merupakan orang yang mudah beradaptasi. Menurutnya tidak jauh berbeda sebelum dan selama pandemi, tidak terlalu mengganggu aktivitasnya dalam berkomunikasi dan bersosialisasi dengan lingkungan sekitar.

\section{Tahap Narasumber pada Empat Kemungkinan (Full Participation, Accomodation, Fight, Flight)}

Berdasarkan wawancara dengan Alvina, selama beradaptasi hingga saat ini, ia sudah berada pada tahap full participation dan telah berdamai dengan keadaan. Selain itu ia sudah mulai terbiasa untuk menghabiskan waktu di kamarnya tanpa harus bersosialisasi dengan orang lain. Menurutnya perubahan yang ia alami selama pandemi ini tidak mengganggu kondisi batinnya karena ia melihat perubahan tersebut dari sisi positif.

\footnotetext{
"Menurut saya selama beradaptasi hingga hari ini, saya sudah berada di tahap full participation, saya sudah berdamai dengan keadaan bahwa kita akan selalu online sampai waktu yang belum ditentukan dan saya juga sudah sangat terbiasa dengan keadaan ini. Sekarang saya lebih banyak menghabiskan waktu di kamar tanpa banyak berinteraksi dengan orang lain dan mungkin karena memang dulunya saya juga bukan orang yang harus selalu bersosialisasi jadi saya tidak merasa adanya tekanan karena menjadi jarang bersosialisasi. Tidak ada gejolak batin dalam diri saya sampai hari ini akan perubahan-perubahan yang saya rasakan selama ini karena saya masih melihat dari sisi yang positif dan baik terhadap diri saya" (Alvina Oeyta, 22 November 2021).
}

Sama seperti Alvina, Caren dan Farel juga berada pada tahap full participation ditunjukan dengan pribadi Farel yang mudah bergaul serta bersosialisasi dan tidak 
mengalami kesulitan dalam beradaptasi. Sedangkan Caren menuturkan bahwa dirinya mudah untuk menyesuaikan diri dengan kondisi sekitar. Menurut Caren yang menjadi poin penting dalam beradaptasi adalah sesuatu yang dapat membuat dirinya nyaman dan aman dalam menjalani aktivitas contohnya seperti melakukan kebiasaan yang sering dilakukan sehari-hari.

\section{Diskusi dan Pembahasan}

Sedangkan menurut narasumber ahli Desi Yunita, interaksi sosial adalah proses saling memengaruhi atau tindakan atau aksi yang berbalas-balasan. Jadi interaksi sosial merupakan proses orang atau individu yang berkomunikasi saling pengaruh dan memengaruhi pikiran dan tindakan, ada hubungan timbal balik yang terjadi, tindakan tersebut dapat berupa simbol-simbol atau konsep-konsep yang dipahami di antara yang berinteraksi (wawancara dengan Desi Yunita melalui aplikasi Whatsapp pada tanggal 10 November 2021 pukul 12:00 WIB).

Berdasarkan hasil temuan penulis terhadap ketiga narasumber, penulis melihat setiap narasumber memiliki kegiatan dan agenda yang berbeda-beda selama menjadi mahasiswa perantau di Jakarta. Narasumber Alvina menjalani aktivitas di luar rumah empat sampai lima kali dalam seminggu karena harus mengikuti kegiatan perkuliahan secara langsung dan menghabiskan waktu yang lama di lingkungan kampus mengisi aktivitasnya selama di organisasi yang ia ikuti. Selama pandemi melanda, aktivitas Alvina menjadi terhambat dan berkurang, berbeda dengan seperti sebelum pandemi.

Desi Yunita menjelaskan bahwa perubahan dapat bersifat memaksa baik secara mikro maupun makro, secara mikro bila individu ingin bertahan pada budaya atau pola gaya hidup konvensional, tetapi realitanya dalam perkembangan zaman jika bertahan pada pola lama, akan banyak menghadapi kendala-kendala dalam proses interaksinya. Sehingga mau tidak mau, akan ada perubahan, bisa diawali dengan modifikasimodifikasi atau penyesuaian pada beberapa aspek, tetapi lama kelamaan dan apabila semua orang sudah pada budaya dan pola yang sama, lambat atau cepat, seseorang akhirnya memutuskan untuk beradaptasi, meski awalnya terpaksa lambat laun akan diterima menjadi kebudayaan baru (Wawancara dengan Desi Yunita melalui aplikasi Whatsapp pada tanggal 10 November 2021 pukul 12:00 WIB).

\section{Simpulan}

Dari penjelasan di atas penulis menyimpulkan beberapa kesimpulan dari hasil penelitian yaitu sebagai berikut:

1. Wabah Covid-19 di Jakarta membawa perubahan sosial di dalam kehidupan mahasiswa perantau sebelum dan selama pandemi.

2. Adanya perubahan sosial, membuat gaya hidup mahasiswa perantau di Jakarta turut berubah menyesuaikan aturan selama pandemi berlangsung seperti menjadi lebih hemat dan sadar untuk mengatur finansial, lebih memperhatikan kesehatan melalui olahraga.

3. Perubahan sosial yang dirasakan mahasiswa perantau menumbuhkan rasa simpati dan peduli terhadap kondisi sesama. Hal ini dilihat berdasarkan pengalaman narasumber yang membantu sesama dalam berbagi makanan serta tingkat emosional akan suatu kejadian yang menimpa individu lain.

4. Perubahan sosial selama pandemi membawa dampak dari berbagai aspek kesehatan, keuangan dan komunikasi. Misalnya sebelum pandemi, mahasiswa perantau jarang berolahraga karena mereka merasa sudah banyak melakukan 
gerakan fisik dengan beraktivitas di luar ruangan seperti berkuliah dan kegiatan luar ruangan lainnya. Tapi setelah pandemi, mulai berolahraga karena merasa hidup statis di kamar tidak baik. Untuk finansial, mahasiswa perantau menjadi lebih berhemat serta menumbuhkan minat untuk memperoleh penghasilan sendiri

\section{Ucapan Terima Kasih}

Penyusunan skripsi ini dapat terlaksana dengan dukungan dan bantuan dari banyak pihak. Oleh karena itu, penulis mengucapkan terima kasih kepada pembimbing penulis, narasumber, semua pihak yang terlibat, dan yang telah membantu penulis selama proses penelitian ini.

\section{Daftar Pustaka}

Herdiansyah, H. (2010). Metodologi Penelitian Kualitatif untuk Ilmu-ilmu Sosial. Jakarta: Salemba Humanika.

Hasanah, S. U. (2018). Adaptasi dan Interaksi Sosial Mahasiswa Afirmasi di Universitas Sumatera Utara. repositori USU, 9-13.

Kotler, P., \& Armstrong, G. (2012). Prinsip-prinsip Pemasaran. Jakarta: Erlangga.

Peter, P. J., \& Olson, J. C. (2014). Perilaku Konsumen dan Marketing Strategy, edisi kesembilan. Jakarta: Salemba.

Raco, J. R. (2010). Metode penelitian Kualitatif, Jenis, Karakteristik, dan Keunggulannya. Jakarta: Gramedia.

Rahmadi. (2011). Pengantar Metodologi Penelitian. Banjarmasin: Antasari Press.

Soekanto, S. (2015). Sosiologi Suatu Pengantar. Jakarta: Raja Grafindo Persada.

Sugiyono. (2013). Metode Penelitian Kuantitatif, Kualitatif dan R\&D. Bandung: Alfabeta.

West, R., \& Turner, L. H. (2012). Pengantar Teori komunikasi Analisis dan Aplikasi . Jakarta: Salemba Humanika.

Wensi, \& Azeharie, S. (2020). Interaksi Sosial antara Kelompok Masyarakat Dayak dan Kelompok Masyarakat Tionghoa di Singkawang. Jurnal Koneksi, 66-75.

WHO. (2021, Agustus). World Health Organization SEA Indonesia. Retrieved from Pertanyaan dan jawaban Terkait Coronavirus: https://www.who.int/indonesia/news/novel-coronavirus/qa/qa-for-public 